\title{
Is it possible to avoid intra-articular screw penetration with minimal use of fluoroscopy in the application of distal radius volar plate?
}

\author{
Distal radius volar plak uygulamasında minimum floroskopi kullanılarak \\ eklem içi vida penetrasyonundan kaçınmak mümkün mü?
}

\author{
Cengiz Aldemir, MD., Fatih Duygun, MD. \\ Department of Orthopedics and Traumatology, Sağlık Bilimleri University, \\ Antalya Training and Research Hospital, Antalya, Turkey
}

\begin{abstract}
Objectives: This study aims to investigate whether or not it is possible to avoid intra-articular screw penetration in the application of distal radius volar plate with minimal use of fluoroscopy and thereby reduce to a minimum the risk of exposure of the surgical team to radiation.
\end{abstract}

Patients and methods: Volar plate with distal screw application with minimal use of fluoroscopy was performed in a total of 50 patients ( 22 males, 28 females; mean age 43.52 years; range 18 to 76 years) with unstable distal radius fracture following reduction of fracture between June 2014 and May 2016. A specially designed volar anatomic plate was applied by creating a $3 \mathrm{~mm}$ gap proximal from the tip of the facet of the lunate fossa.

Results: No intra-articular screw complication was observed during plate-screw applications that we performed by using fluoroscopy at a minimum level and paying attention to the surgical technique described with the plate designed by giving a specific angle to screw beds. During the operation, fluoroscopy was performed at a minimum level and no finding was observed which could suggest use of intra-articular screw. No findings of restriction in wrist movements, locking or friction were observed intra- or postoperatively.

Conclusion: With improvements in the design of the volar plate and the distal locking screw bed, it is possible to rule out the possibility of intra-articular screw complications and the need for surgical re-correction in the early-term, and to reduce to a minimum the risk of exposure of the surgical team to radiation.

Keywords: Distal radius fracture; fluoroscopy; volar anatomic plate.
ÖZ

Amaç: Bu çalışmada distal radius volar plak uygulamasında minimum floroskopi kullanılarak eklem içi vida penetrasyonundan kaçınmanın ve böylece cerrahi ekibin radyasyona maruz kalma riskinin minimuma indirilmesinin mümkün olup olmadığı araştırıldı.

Hastalar ve yöntemler: Haziran 2014 - Mayıs 2016 tarihleri arasında instabil distal radius kırı $\breve{g}_{1}$ olan 50 hastada (22 erkek, 28 kadın; ort. yaş 43.52 yıl; dağılım $18-76$ yıl) kırık redüksiyonunu takiben distal vida ile volar plak uygulaması minimum floroskopi kullanımı ile gerçekleştirildi. Özel tasarlanmış volar anatomik plak lunat fossanın fasetinin ucundan proksimale doğru $3 \mathrm{~mm}$ mesafe oluşturularak uyguland1.

Bulgular: Vida yataklarına özel açı verilerek tasarlanmış plak ile tarif edilen cerrahi tekniğe dikkat ederek ve minimum düzeyde floroskopi kullanarak yaptığımız plakvida uygulamalarında eklem içi vida komplikasyonu ile karşılaşılmadı. Ameliyat sırasında floroskopi minimum düzeyde uygulandı ve eklem içi vida kullanımını düşündürecek herhangi bir bulguya rastlanmadı. Ameliyat sirasında ve sonrasında el bileği hareketlerinde kisitlılık, takılma ya da sürtünme bulgularına rastlanmadı.

Sonuç: Volar plak ve distal kilit vida yatağı tasarımındaki iyileştirmeler ile eklem içi vida komplikasyonları olasılığını ve erken dönem tekrar cerrahi düzeltme ihtiyacını ortadan kaldırmak ve cerrahi ekibin radyasyona maruz kalma riskini minimuma indirmek mümkündür.

Anahtar sözcükler: Distal radius kırığı; floroskopi, volar anatomik plak.

- Received: August 24, 2016 Accepted: January 04, 2017

- Correspondence: Cengiz Aldemir, MD. Antalya Eğitim ve Araştırma Hastanesi Ortopedi ve Travmatoloji Kliniği, 07030 Muratpaşa, Antalya, Turkey. Tel: +90 532 - 2953353 e-mail: aldemircengiz@yahoo.com 
Complications may be seen such as flexor and extensor tendon irritation and tendon ruptures, carpal tunnel syndrome, complex regional pain syndrome, delayed union, and intra-articular penetration of screws in the application of volar plate for the treatment of distal radius fractures. ${ }^{[1]}$

Intra-articular penetration of distal screws is not a rare complication. Factors which can lay the ground for and result in intra-articular penetration of the screws include plate design (distal mobile screw holes, non-angulated free holes, incompatibility of the plate and distal radius volar interface), application errors (inattention to the watershed line during application of the plate, incorrect positioning of the plate), inattention to the depth of the lunate fossa, and super-positioning of the screws. ${ }^{[2,3]}$

When applying a volar distal radius plate, there are five important anatomic formations that require attention; the volar radial tuberosity, volar radial ridge, fibrous transition zone, watershed line, and the lunate facet buttress. ${ }^{[4]}$ Another point which has been described in respect of ideal placement of the plate and collapse which could occur in the future is the distal dorsal cortical distance, which should be $6 \mathrm{~mm}$ or less. ${ }^{[5]}$

However, despite an appropriate surgical technique paying attention to all these anatomic forms, there is a need for fluoroscopy when applying a volar plate. Radiation is known to be harmful for both the surgeon and the anesthesia team. ${ }^{[6]}$ There should be an awareness of the long-term harm of repeated exposure to radiation, including usage at small doses. ${ }^{[7]}$ It is important to reduce these harmful effects to a minimum. ${ }^{[6]}$ Checking with fluoroscopy is recommended when seating the volar plate in the distal radius, when applying the screws in the head section of the plate, at the stage of fixing the screws in the stem and head section, and at the end of surgery. ${ }^{[8]}$

In this study, we aimed to investigate whether or not it is possible to avoid intra-articular screw penetration in the application of distal radius volar plate with minimal use of fluoroscopy and thereby reduce to a minimum the risk of exposure of the surgical team to radiation.

\section{PATIENTS AND METHODS}

Between June 2014 and May 2016, surgery was applied to 50 patients (22 males, 28 females; mean age 43.52 years; range 18 to 76 years) who presented at our clinic with an unstable distal radius fracture. The fractures were in the right-side radius in 16 patients $(32 \%)$ and in the left-side radius in $34(68 \%)$. The mean follow-up period was 12 months. Criteria of instability were accepted as distance between the intra-articular fracture fragments of $>1 \mathrm{~mm}$, stepoff between intra-articular fracture fragments of $>1 \mathrm{~mm}$, changes in the radial curve of $\geq 5^{\circ}$, changes in volar angulation of $>10^{\circ}$, changes in radial height of $>5 \mathrm{~mm}$, fracture of $>50 \%$ of the dorsal or volar joint surface and shift of $>5 \mathrm{~mm}$ between major fracture fragments. ${ }^{[9,10]}$ This technique was not used on $\mathrm{AO}$ C3 type fractures.

\section{Surgical technique}

Patients with unstable distal radius fracture underwent surgery with a distal radius anatomic volar plate (C-M Smart, Hipokrat, Izmir, Turkey). The plate is a truly anatomic plate, comprising head and stem
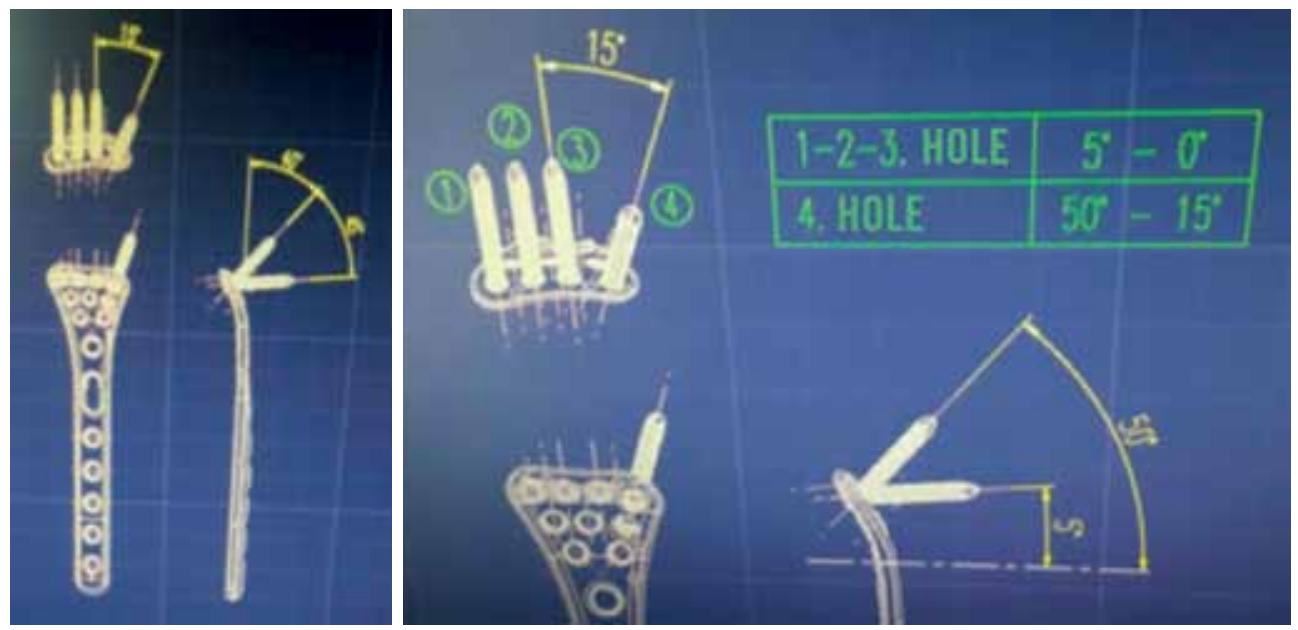

Figure 1. Technical images showing plate structure and screw hole angles. 


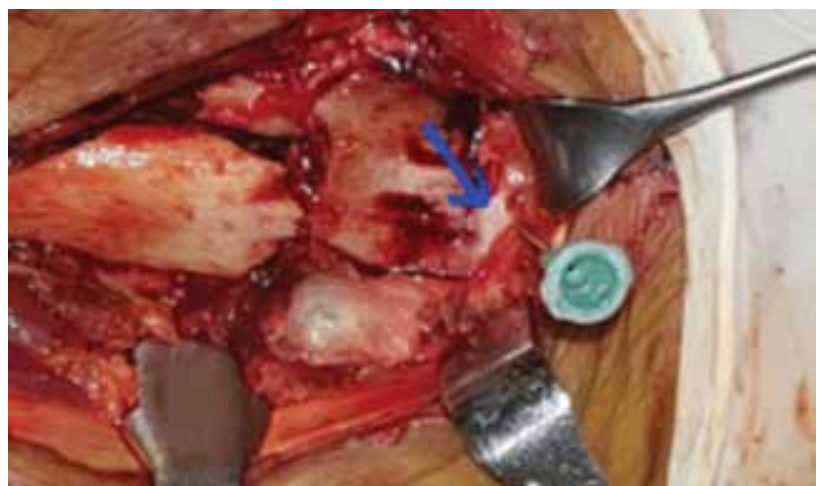

Figure 2. Perioperative image of injector needle entering radiocarpal joint almost from tip of lunate fossa facet.

sections, compatible with the distal radius anatomy in three planes. The plate has been designed with the screw angles in the head section at angles suitable to prevent joint penetration of the screws (Figures 1). The stem section is a spiral shape compatible with the distal radius anatomy. All the screws in the head section of the plate were applied without fluoroscopy. Before the operating field was closed, posteroanterior (PA) and PA tilt $\left(11^{\circ}\right)$ and lateral and lateral tilt $\left(15.23^{\circ}\right)$ were checked with fluoroscopy.

The volar surface was entered with a $10-12 \mathrm{~cm}$ incision over the flexor carpi radialis. The radial artery together with the flexor carpi radialis tendon were moved laterally. The other flexor tendons were retracted medially and the pronator quadratus muscle was reached. The muscle together with the periosteum was raised in the form of a flap and moved to the ulnar side. Following fracture reduction, an injector needle was placed into the radio carpal joint just at the tip of the lunate fossa facet (Figure 2). By creating a $3 \mathrm{~mm}$ gap towards the

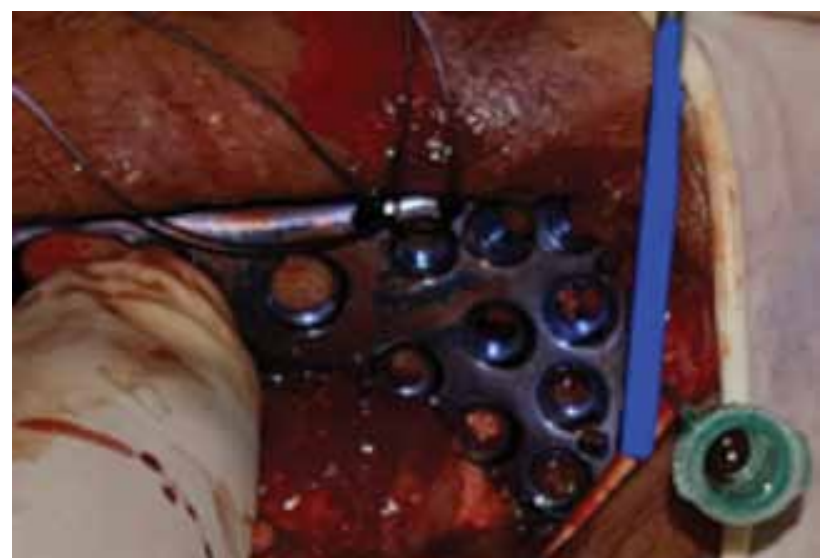

Figure 3. A $3 \mathrm{~mm}$ gap was created between needle and distal edge of volar anatomic plate. proximal from the needle, the distal radius anatomic volar plate was placed in the pronator fossa in such a manner that the distal edge of the plate would not cross the watershed line (Figure 3). First, the screws were placed over the oval holes in the plate stem. Then, the head section of the plate was seated by applying two screws to the specifically angulated oblique screw bed in the most proximal section of the head of the plate. The third step was to apply screws, again to the specifically angulated oblique screw bed, next to the lunate fossa in the ulnar distal of the plate. Then, in sequence, two screws were entered to the styloid and other screws were placed. During the operation, wrist movements were checked and checking was applied once with fluoroscopy, then finally, the pronator quadratus muscle was fixed to the two holes located at the radial edge of the plate (Figure 4).

\section{RESULTS}

After advancement of the screws, it was checked during the operation if there was any restriction of wrist movements, locking or friction. Whether or not screws were within the joint was checked with a minimal use of fluoroscopy on the operating table before the operating field was closed in all patients (Figures 5). No intra-articular screw was determined in any patient. No findings or imaging suggestive of intra-articular penetration of the screw to the radiocarpal joint were encountered in the routine postoperative clinical or radiographic follow-ups.

\section{DISCUSSION}

Volar plate application is the gold standard treatment method for unstable, distal radius fractures. ${ }^{[11]}$ The application of subchondral screws is

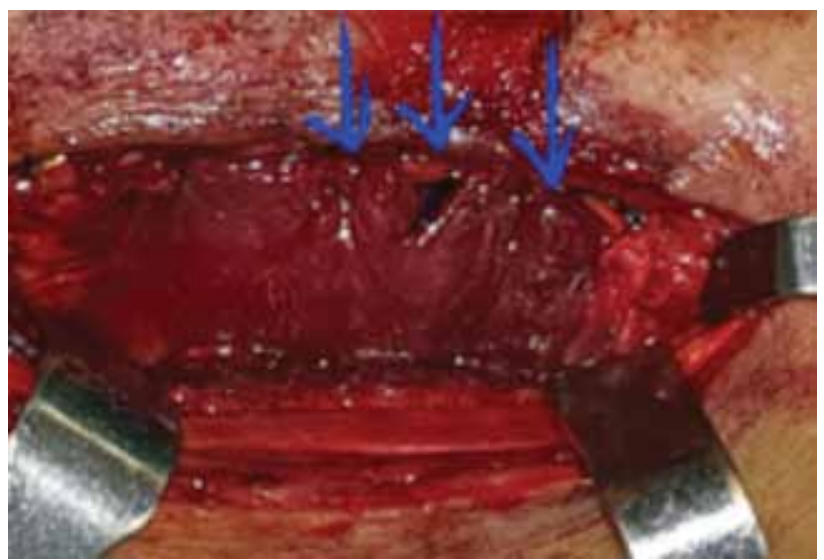

Figure 4. Closure of pronator quadratus muscle with holes in plate edge. 


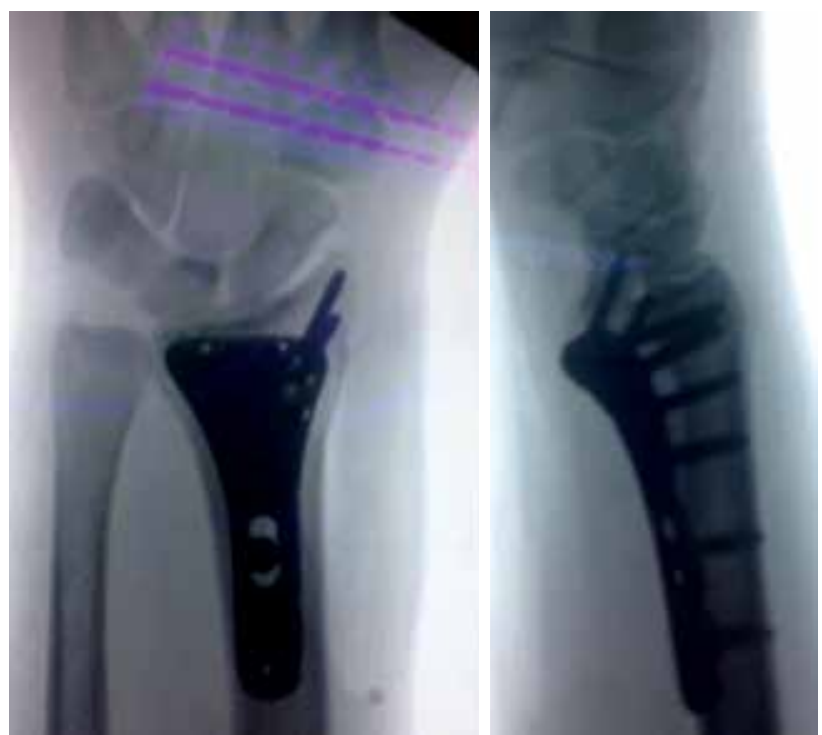

Figure 5. Postoperative fluoroscopy control.

particularly recommended because of the supportive effect. ${ }^{[12]}$ However, this increases the risk of the screw penetrating the joint in angled plates. Intraarticular screw penetration is known to trigger

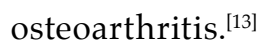

To determine intra-articular screw penetration in the treatment of distal radius fractures with volar plate, fluoroscopic methods (rotational fluoroscopy, 3-D fluoroscopy), standard radiographs (PA and lateral images), $11^{\circ} \mathrm{PA}$ tilt and $22^{\circ}$ lateral tilt images and tomography are recommended..$^{[14]}$ The distal radius anatomy is complex and intraoperative imaging is difficult. Intra-articular screw penetration may not be determined on radiographs $s^{[15]}$ and the correct extraarticular position of the subchondral screw may not be obtained on standard PA and lateral fluoroscopic images. ${ }^{[16-18]}$ In a study by Mehling et al., ${ }^{[19]}$ volar plate was applied to 51 patients with unstable, distal radius fractures and 3-D tomography was taken in addition to intraoperative 2-D fluoroscopy. Incorrect placement of the screw was determined in $31.3 \%$ of the patients and immediate correction was made during the operation.

In a cadaver study by Soong et al., ${ }^{[20]}$ tomography was not used for the evaluation of intra-articular screw placement, but examination was made using standard PA, $11^{\circ}$ tilt PA, standard lateral and $15^{\circ}, 23^{\circ}$ and $30^{\circ}$ lateral tilt fluoroscopic images. It was stated that low angle lateral images were more specific for ulnar screws and high angle images for radial screws. In the current study, evaluation was made with standard $\mathrm{PA}, 11^{\circ}$ tilt $\mathrm{PA}$, standard lateral and $15^{\circ}$ and $23^{\circ}$ lateral tilt fluoroscopic images.
In a previous study conducted by the current study team using this technique on dry bones and cadavers, no intra-articular screw penetration was seen. ${ }^{[2]}$ Therefore, no need was felt for any need for tomography in the cases of the current study.

During the application of a volar plate, it is known that not only the surgeon, but the whole team, including the anesthetist, are exposed to radiation, with the thyroid, gonads, hands and eyes particularly affected. ${ }^{[6,21]}$ Reducing the amount of radiation exposure is important for the whole surgical team. In a study by Mehlman et al. ${ }^{[2]}$ of fluoroscopy in general orthopedic operations, clear exposure to radiation was seen at distances of $\leq 70 \mathrm{~cm}$ from the fluoroscopy beam. In another study by Müller et al., ${ }^{[6]}$ it was shown that the first assistant was exposed to more radiation than the surgeon in the application of distal volar plate.

Therefore, surgery should be planned with plates with specifically angled screw beds, which are compatible with the radius volar anatomy. In this way, as demonstrated by the current cases, intra-articular screw complications can be avoided and the amount of radiation to which the surgical team is exposed can be reduced. ${ }^{[23]}$

The plates to be applied must be absolutely compatible with the distal radius anatomy, should have holes at angles not going to the joint surface, and must be seated $3 \mathrm{~mm}$ proximal to the tip of the lunate facet at the level of the lunate fossa.

This study has some limitation, because of the fact that we didn't measure distal dorsal cortical distance.

In conclusion, with improvements in the design of the volar plate and the distal locking screw bed, it is possible to rule out the possibility of intra-articular screw complications and the need for surgical re-correction in the early-term, and to reduce to a minimum the risk of exposure of the surgical team to radiation.

\section{Declaration of conflicting interests}

The authors declared no conflicts of interest with respect to the authorship and/or publication of this article.

\section{Funding}

The authors received no financial support for the research and/or authorship of this article.

\section{REFERENCES}

1. Arora R, Lutz M, Hennerbichler A, Krappinger D, Espen D, Gabl M. Complications following internal fixation of 
unstable distal radius fracture with a palmar locking-plate. J Orthop Trauma 2007;21:316-22.

2. Aldemir C, Önder M, Doğan A, Duygun F, Oğuz N. Morphometric anatomic study and clinical significance of lunate fossa. [Article in Turkish] Eklem Hastalik Cerrahisi 2015;26:27-30.

3. Orbay JL, Touhami A. Current concepts in volar fixed-angle fixation of unstable distal radius fractures. Clin Orthop Relat Res 2006;445:58-67.

4. Imatani J, Akita K, Yamaguchi K, Shimizu H, Kondou H, Ozaki T. An anatomical study of the watershed line on the volar, distal aspect of the radius: implications for plate placement and avoidance of tendon ruptures. J Hand Surg Am 2012;37:1550-4.

5. Vosbikian MM, Ketonis C, Huang R, Ilyas AM. Optimal Positioning for Volar Plate Fixation of a Distal Radius Fracture: Determining the Distal Dorsal Cortical Distance. Orthop Clin North Am 2016;47:235-44.

6. Müller MC, Strauss A, Pflugmacher R, Nähle CP, Pennekamp $\mathrm{P}$, Burger $\mathrm{C}$, et al. Evaluation of radiation exposure of personnel in an orthopaedic and trauma operation theatre using the new real-time dosimetry system "dose aware". Z Orthop Unfall 2014;152:381-8. [Article in German]

7. Khan IA, Kamalasekaran S, Fazal MA. Risk of ionising radiation to trainee orthopaedic surgeons. Acta Orthop Belg 2012;78:106-10.

8. Protopsaltis TS, Ruch DS. Volar approach to distal radius fractures. J Hand Surg Am 2008;33:958-65.

9. Bradway JK, Amadio PC, Cooney WP. Open reduction and internal fixation of displaced, comminuted intra-articular fractures of the distal end of the radius. J Bone Joint Surg [Am] 1989;71:839-47.

10. Fernandez DL, Geissler WB. Treatment of displaced articular fractures of the radius. J Hand Surg Am 1991;16:375-84.

11. Simic PM, Weiland AJ. Fractures of the distal aspect of the radius: changes in treatment over the past two decades. Instr Course Lect 2003;52:185-95.

12. Drobetz H, Kutscha-Lissberg E. Osteosynthesis of distal radial fractures with a volar locking screw plate system. Int Orthop 2003;27:1-6.
13. Tarallo L, Mugnai R, Zambianchi F, Adani R, Catani F. Volar plate fixation for the treatment of distal radius fractures: analysis of adverse events. J Orthop Trauma 2013;27:740-5.

14. de Brecht $M$, Yamagishi N. Combining sparseness and smoothness improves classification accuracy and interpretability. Neuroimage 2012;60:1550-61.

15. Borggrefe J, Bolte H, Worms W, Mahlke L, Seekamp A, Menzdorf L, et al. Comparison of intraoperative flat panel imaging and postoperative plain radiography for the detection of intraarticular screw displacement in volar distal radius plate ostheosynthesis. Orthop Traumatol Surg Res 2015;101:913-7.

16. Park DH, Goldie BS. Volar plating for distal radius fractures-do not trust the image intensifier when judging distal subchondral screw length. Tech Hand Up Extrem Surg 2012;16:169-72.

17. Thomas AD, Greenberg JA. Use of fluoroscopy in determining screw overshoot in the dorsal distal radius: a cadaveric study. J Hand Surg Am 2009;34:258-61.

18. Tweet ML, Calfee RP, Stern PJ. Rotational fluoroscopy assists in detection of intra-articular screw penetration during volar plating of the distal radius. J Hand Surg Am 2010;35:619-27.

19. Mehling I, Rittstieg P, Mehling AP, Küchle R, Müller LP, Rommens PM. Intraoperative C-arm CT imaging in angular stable plate osteosynthesis of distal radius fractures. J Hand Surg Eur Vol 2013;38:751-7.

20. Soong M, Got C, Katarincic J, Akelman E. Fluoroscopic evaluation of intra-articular screw placement during locked volar plating of the distal radius: a cadaveric study. J Hand Surg Am 2008;33:1720-3.

21. Hoffler CE, Ilyas AM. Fluoroscopic radiation exposure: are we protecting ourselves adequately? J Bone Joint Surg [Am] 2015;97:721-5.

22. Mehlman CT, DiPasquale TG. Radiation exposure to the orthopaedic surgical team during fluoroscopy: "how far away is far enough?". J Orthop Trauma 1997;11:392-8.

23. Atik OŞ. Do we surgeons perform surgery only? Eklem Hastalik Cerrahisi 2016;27:123-4. 